\title{
Evaluation of a Newly Developed Laser Pen as a Home Care Device for Pain Reduction of Recurrent Aphthous Stomatitis (Preliminary Study)
}

\author{
Maziar Mir'1, Seyed Masoud Mojahedi', Hassan Adalatkhah², Jan Tunér³, \\ Amir Mansour Shirani4* ${ }^{*}$ Roshan Babaalipour5, Masoud Shabani1,2 \\ ${ }^{1}$ Conservative Dentistry, RWTH Internatıonal Academy, Aachen, Germany \\ ${ }^{2}$ Deputy for Research, Ardebil University of Medical Sciences, Ardebil, Iran \\ ${ }^{3}$ Private Dental Clinic, Grängesberg, Sweden \\ ${ }^{4}$ Oral Medicine Department, Dental School of Islamic Azad University, Khorasgan, Iran \\ ${ }^{5}$ Science Department, Islamic Azad University, Ardebil, Iran \\ Email: ${ }^{*}$ m.shabani@arums.ac.ir
}

Received 20 December 2014; accepted 4 January 2015; published 14 January 2015

Copyright (C) 2015 by authors and Scientific Research Publishing Inc.

This work is licensed under the Creative Commons Attribution International License (CC BY). http://creativecommons.org/licenses/by/4.0/

(c) (i) Open Access

\section{Abstract}

Objective: The aim of this survey is to evaluate the effect of a new developed laser pen as a home care device for patients' pain reduction with recurrent aphthous stomatitis. Background data: Recurrent aphthous stomatitis (RAS) is one of the most common and painful ulcers in the oral cavity. Low Level Laser Therapy (LLLT) has been used successfully for reducing pain and healing time in comparison with corticosteroids and placebo in some studies. But these treatments are done in the clinics and it seems that there is no report of the laser treatment as a home care device up to this study. Methods: This was a prospective, randomized trial pilot study. Thirty patients with RAS were divided into three similar groups. The group one $(n=10)$ was treated with a diode laser, 660 $\mathrm{nm}, 40 \mathrm{mw}$, continuous wave, $1.2 \mathrm{~J}, 6 \mathrm{~J} / \mathrm{cm}^{2}$, for five consecutive days (twice per day, 30 seconds each session). The second group $(n=10)$ was treated with a topical triamcinolone (adcortyl in orabase) ointment four times per day and the third group $(n=10)$ was treated with placebo (red light pen) the same way as Group 1. All the patients were evaluated with a Visual Analogue Scale (VAS) before and after treatment on the consecutive days. The data was analysed by one way ANOVA and PostHoc tests. Results: The results show that the laser pen and triamcinolon in orabase ointment have similar results and both have better results than placebo in the control of the recurrent aphthous stomatitis pain (p value: 0.001 ). Conclusion: In this clinical pilot study the laser pen as a home care device seems to be useful for the treatment of RAS.

\footnotetext{
${ }^{*}$ Corresponding author.
}

How to cite this paper: Mir, M., et al. (2015) Evaluation of a Newly Developed Laser Pen as a Home Care Device for Pain Reduction of Recurrent Aphthous Stomatitis (Preliminary Study). International Journal of Clinical Medicine, 6, 19-25. 


\section{Keywords}

\section{Low Level Laser Therapy, Recurrent Aphthous Stomatitis, Pain, Corticosteroid}

\section{Introduction}

Recurrent aphthous stomatitis (RAS) is a common problem, particular to the mouth, and typically starts in childhood or adulthood as recurrent small, round or ovoid ulcers with circumscribed margins, erythematous haloes, and yellow or gray floor. RAS has three clinical types: minor, major and herpetiform ulcers. Ulcers with similar clinical features (aphthous-like ulcers) may be because of some systemic conditions such as Behçet syndrome, auto-inflammatory syndromes, gastrointestinal disease or immune defects. The etiology of recurrent aphthous stomatitis (RAS) is not entirely clear. A genetic basis exists for some RAS and involvement of the cell-mediated mechanisms is possible, but the precise immunopathogenesis remains unclear. Phagocytic and cytotoxic T cells probably aid in destruction of oral epithelium that is directed and sustained by local cytokine release.

Comparing with control subjects and patients with inactive RAS patients with active RAS have an increased proportion of gamma-delta T cells. Gamma-delta T cells may be involved in antibody-dependent cell-mediated cytotoxicity (ADCC). Also in comparison with control subjects, individuals with RAS have raised serum levels of cytokines such as interleukin-6 (IL-6) and (IL-2R), soluble intercellular adhesion modules (ICAM), vascular cell adhesion modules (VCAM), and E-selectin. However, some of these are not related to disease activity [1]-[4]. LLLT has been reported as useful treatment for several cases, such as reduction of the destructive interleukins and tumour necrotizing factor (TNF- $\alpha$ ) production, improvement of the immune system function, and reduction of pain and the healing time period [5]-[12].

Lasers (high power and low power) have been used in some case reports and studies for pain reduction and shortening healing time of RAS [13]-[32]. Most of these reports are focusing on office treatment. But many patients have recurrent lesions and there are no known home care devices for laser treatment of RAS. Therefore, to assist patients in using lasers at home by themselves, a low level laser is inserted in a pen-like device. This laser is called Low Level Laser Aphthous Pen (LLLAP) and it seems that it is the first time that such a device is introduced to dental professionals. Therefore, the aim of this pilot study is to evaluate the pain reduction efficiency of this particular instrument.

\section{Material and Method}

A prospective randomized trial was conducted with 30 patients. Inclusion criteria were: Existence of at least one minor aphthous ulcer smaller than $5 \mathrm{~mm}$ (Figure 1), satisfaction and ability to take part in the study, fulfillment of the patient consent form according to the Code of Ethics and having new lesions in the first two days. Exclusion criteria were: Pregnancy, carcinoma, taking steroids or anticoagulant and anti-inflammatory agents, eye problems or mental retardation or impairment and patients with aphthous like ulcers with signs and symptoms of systemic diseases like Behçet syndrome, auto-inflammatory syndromes, gastrointestinal disease, or immune defects and severe anemia. Ethically all these patients were treated as well but were not counted as study cases. There is not any side effect with LLLT. Doses of laser energy near the therapeutic window will not cause negative effects. The worst result with LLLT is that nothing happens. But irradiation over thyroid glands and in the cases of coagulation disorder and malignancy the low level laser therapy must be avoided [10]. The samples were allocated into three groups: Group 1 received laser therapy with new Low level laser aphthous pen (LLLAP) Figure 2, registration number in Iran: 72619 . Group 2 received topical triamcinolone acetonide $0.1 \%$ in orabase (gelatin, pectin, and carboboxymethylcellulose sodium in Plastibase ${ }^{\circledR}$ (Plasticized Hydrocarbon Gel), a polyethylene and mineral oil gel base) (Adcortyl in Orabase, Bristol-Myers Squibb Company) and Group 3 received placebo red light emitting diode (red LED light).

Laser parameters were: InGaAlP (indium gallium aluminium phosphid) diode laser, wavelength $660 \mathrm{~nm}$, continuous, $40 \mathrm{~mW}$, irradiation diameter $3 \mathrm{~mm}$, spot size $0.19625 \mathrm{~cm}^{2}$, 30 seconds, $1.2 \mathrm{~J}, 6 \mathrm{~J} / \mathrm{cm}^{2}$ twice per day for five consecutive days, near noncontact mode and near at a perpendicular angle (Figure 3).

But patients were educated in how to use the laser; they should not stare into the beam or look directly with optical instruments and it should be kept out of children. 


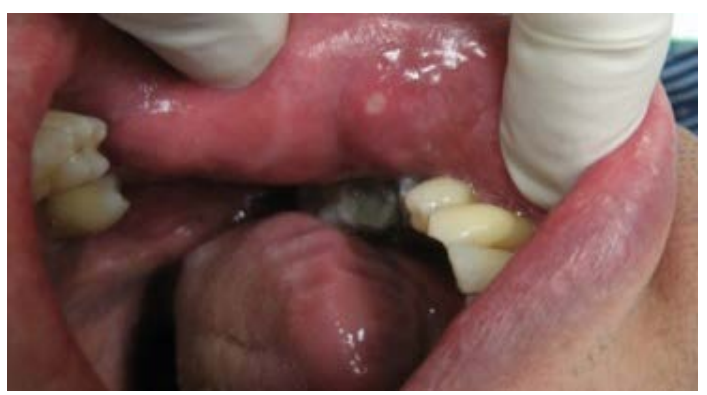

Figure 1. Minor aphthous ulcer.

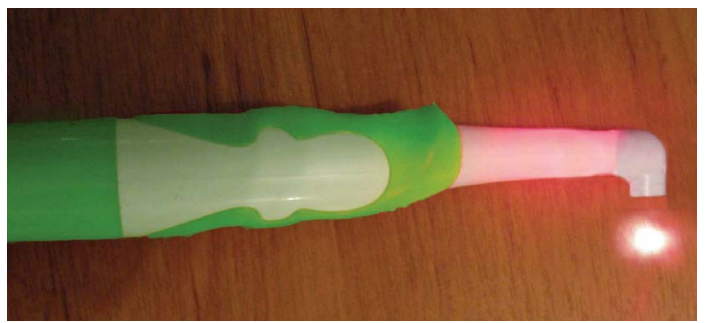

Figure 2. Laser irradiation with aphthous laser pen.

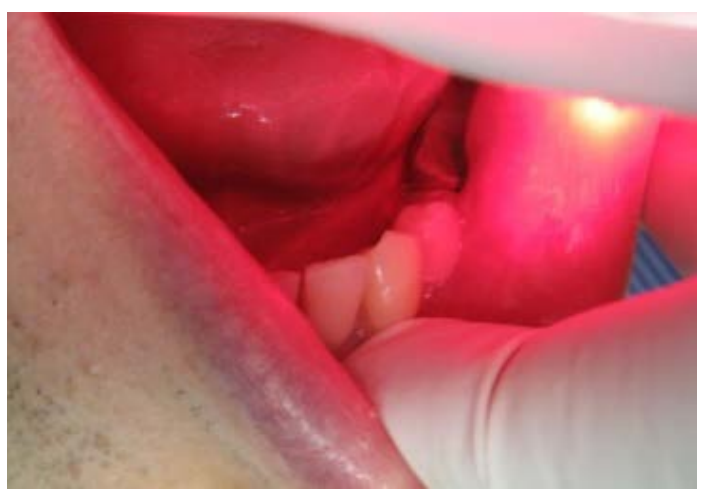

Figure 3. Laser irradiation with aphthous laser pen.

The Research Ethical Committee (REC) approval was adopted with number of ARUMS.REC. 1391023 for this research from Ardebil University of Medical Sciences (ARUMS).

The VAS scale was used for evaluation of pain, in the range of 0 to 10 so that in 0 was no pain and in 10 the pain was so sever. The evaluations were performed before treatment and immediately after irradiation and every day during the first five days. The data were analysed by one way ANOVA and PostHoc tests.

\section{Results}

Thirty patients participated in the study, 16 were men and 14 were women. The location of minor RAS was upper lip in 20 patients and lower lip in 10 patients. Also their mean of age was 43 years.

Before treatment there was no significant VAS difference between the groups by one way ANOVA data analysis, so that the VAS scale for laser group was 7.4 and for placebo group was 6.8 also 6.8 for ointment group, but according to Table 1 and based on confidence interval (CI) 95\% there is no difference between groups significantly ( $\mathrm{p}$ value is bigger than 0.05 ). After treatment immediately after the first session and during the first five days $(p=0.001)$ there was significant difference between the LLLT/Adcortyl groups and the placebo group .The data for Mean, Standard Deviation and PostHoc test results are presented in Table 1. There was no significant difference between laser and Adcortyl groups but both were significantly better than the red light pen. Chart 1 shows the pain reduction during 5 consecutive days among the groups. The healed lesion can be seen in Figure 4. 
Table 1. Result of PostHoc test for multiple comparisons between groups.

\begin{tabular}{|c|c|c|c|c|c|c|}
\hline Variable & $\mathrm{N}$ & Mean & Std.D & Groups & Sig & CI95\% \\
\hline VAS before treatment Laser & 10 & 7.4 & 1.07 & Laser-Ointment & 0.56 & $-0.8-2.04$ \\
\hline Placebo & 10 & 6.8 & 1.39 & Laser-Placebo & 0.56 & $-0.8-2.04$ \\
\hline Ointment & 10 & 6.8 & 1.39 & Ointment-Placebo & 1 & $-1.44-1.44$ \\
\hline VAS imm. after treatment Laser & 10 & 1.8 & 0.42 & Laser-Ointment & 0.3 & $-1.6-0.41$ \\
\hline Placebo & 10 & 6.4 & 5.8 & Laser-Placebo & 0 & $-5.61--3.95$ \\
\hline Ointment & 10 & 2.4 & 0.51 & Ointment-Placebo & 0 & $-5.01--2.9$ \\
\hline VAS $1^{\text {st }}$ day after treatment Laser & 10 & 1.6 & 0.51 & Laser-Ointment & 0.3 & $-1.6-0.47$ \\
\hline Placebo & 10 & 5.8 & 1.3 & Laser-Placebo & 0 & $-5.2--3.1$ \\
\hline Ointment & 10 & 2.2 & 0.78 & Ointment-Placebo & 0 & $-4.6--2.5$ \\
\hline VAS $2^{\text {nd }}$ day after treatment Laser & 10 & 1 & 0.6 & Laser-Ointment & 0.19 & $-1.91-0.31$ \\
\hline Placebo & 10 & 5.2 & 1.3 & Laser-Placebo & 0 & $-5.3--3.08$ \\
\hline Ointment & 10 & 1.8 & 0.78 & Ointment-Placebo & 0 & $2.28-4.51$ \\
\hline VAS $3^{\text {rd }}$ day after treatment Laser & 10 & 1 & 0.6 & Laser-Ointment & 0.74 & $-1.7-0.96$ \\
\hline Placebo & 10 & 4.4 & 1.7 & Laser-Placebo & 0 & $-4.7--2.03$ \\
\hline Ointment & 10 & 1.4 & 1.07 & Ointment-Placebo & 0 & $-4.3--1.63$ \\
\hline VAS $4^{\text {th }}$ day after treatment Laser & 10 & 0.8 & 0.42 & Laser-Ointment & 0.9 & $-0.97-1.37$ \\
\hline Placebo & 10 & 3.6 & 1.71 & Laser-Placebo & 0 & $-3.9--1.6$ \\
\hline Ointment & 10 & 0.6 & 0.51 & Ointment-Placebo & 0 & $1.82-4.17$ \\
\hline VAS $5^{\text {th }}$ day after treatment Laser & 10 & 0.6 & 0.51 & Laser-Ointment & 1 & $-1.01-1.01$ \\
\hline Placebo & 10 & 2.8 & 1.39 & Laser-Placebo & 0 & $-3.2--1.1$ \\
\hline Ointment & 10 & 0.6 & 0.51 & Ointment-Placebo & 0 & $-3.2--1.1$ \\
\hline
\end{tabular}

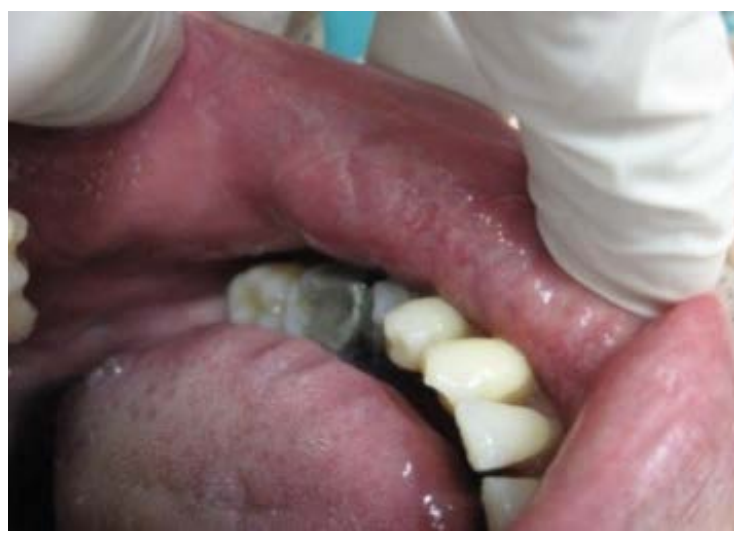

Figure 4. 4 days after treatment.

\section{Discussion}

There are many treatments considered for RAS. Relief of pain and reduction of ulcer duration are the main goals of therapy. Topical corticosteroids remain the mainstays of treatment [4]. Thus, in this study one group receives topical Adcortyl in orabase for better comparison. 


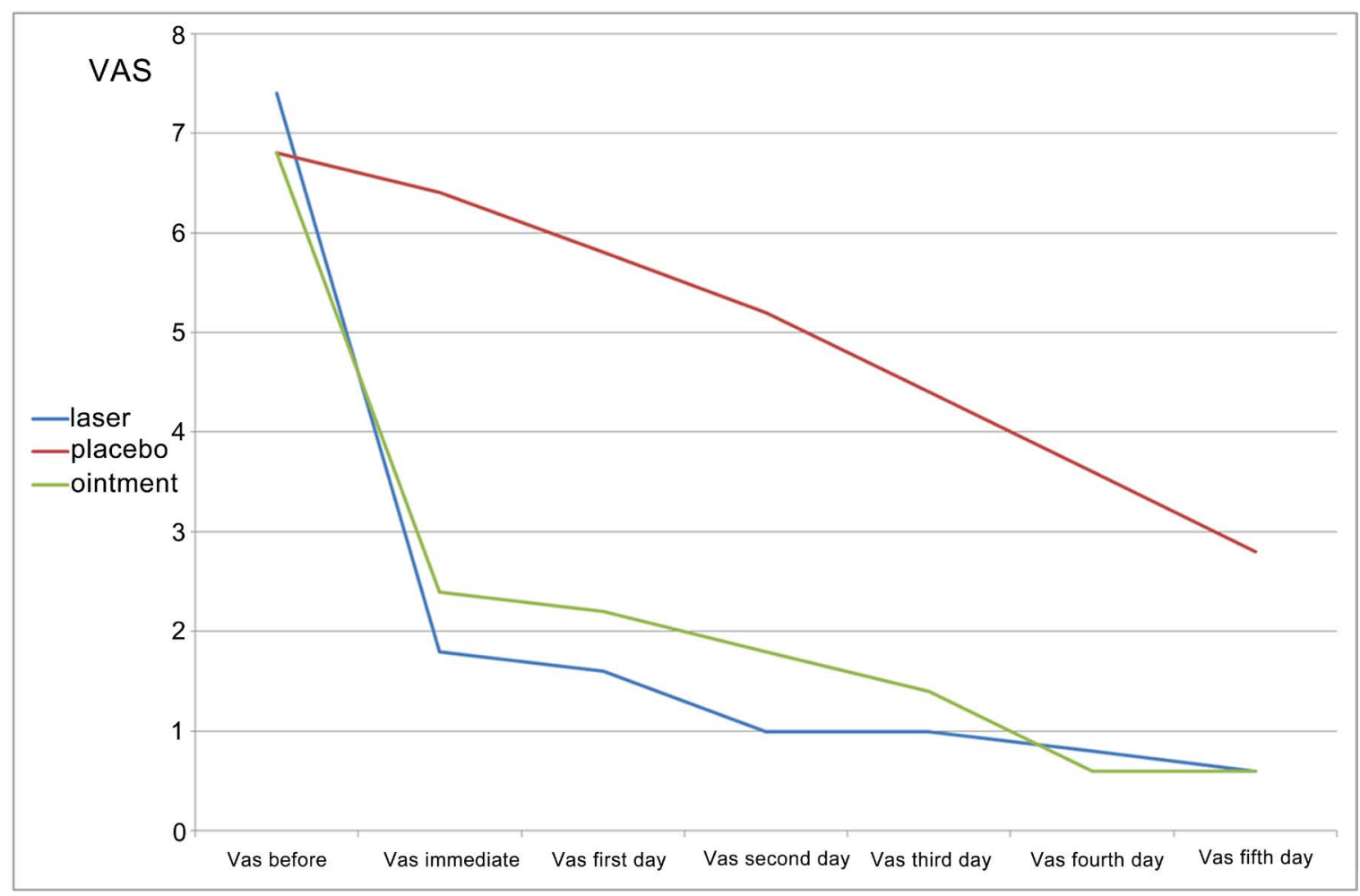

Chart 1. Pain reduction during 5 consecutive days among intervention groups.

Different kinds of laser were successfully used in studies for treatment of RAS. The GaAlAs diode laser [19], He-Ne laser [16] [17], argon laser [20], InGaAlP laser [14] [21], Nd:YAG laser [22] [29], diode $830 \mathrm{~nm}$ [29], GaAs (904 nm) [24], $\mathrm{CO}_{2}$ [26] [30] [31], diode laser [32] were used in case reports and studies. For cases with aphthous like lesion in Behçet syndrome, $\mathrm{CO}_{2}$ laser [23] and $\mathrm{GaAs}(904 \mathrm{~nm}$ ) [25] were used successfully. For cases with aphthous-like ulcer in AIDS (Acquired Immune Deficiency Syndrome) cases, diode $660 \mathrm{~nm}$ laser were used with good result [27]. (As the low level laser can modulate inflammatory mediator such as TNF-alpha, IL-6 and others, reduction of pain can be achived.) The healing of the aphthous ulcer can be attributed to the growth of the cellular activity, especially fibroblast, keratinocytes and immune cells. Therefore wound healing and boosting of the natural function can be achieved.

In this study laser pen is statistically better than laser placebo in pain reduction. This is similar to other studies [21]. The laser pen statistically has a similar efficiency to topical corticosteroids (as a routine treatment) in pain reduction. This finding is similar to other studies [24] [29]. In the present study only pain reduction is evaluated. But in the Salman study [24] the laser treatment group had a shorter healing time in comparison to Adcortyl. Laser therapy reduces healing time in recurrent aphthous stomatitis in comparison to control group (topical lidocaine) in some studies [33]. Da silva [34] et al. in their meta analysis could show that laser therapy speeds up the process of tissue repair. Our findings contrast with the findings of Howell [35] et al. who applied a HeNe laser $\left(633 \mathrm{~nm}, 0.34 \mathrm{~J} / \mathrm{cm}^{2}\right)$ for aphthous lesions. So that they found there is no significant difference between untreated ulcers and laser-treated ulcers. Also de Souza [14] et al. conducted evaluation of LLLT (InGaAlP diodelaser, $670 \mathrm{~nm}, 3 \mathrm{~J} / \mathrm{cm}^{2}$ ) in the treatment of RAS. They observed that LLLT with a topical steroid reduced pain levels after the first LLLT session. But, the pain reduction was not statistically significant. There are some studies that are agreed with our study. Margit [36] et al. in their study used LLLT equipment with a higher wavelength $(809 \mathrm{~nm})$ and output $\left(6.3 \mathrm{~J} / \mathrm{cm}^{2}\right)$ and they found the positive results on pain reduction also some metaanalysis could reveal the positive effect of low level laser therapy for wound healing and pain reduction of ulcers for example the meta analysis that was done by Enwemeka [37] et al. and Woodruff et al. [38] positive or negative results in low level laser therapy can be attributed to incorrect energy density. It seems in our study energy density was enough for pain reduction of RAS.

Most studies are focusing on in-office treatment. The low level laser therapy often requires additional treat- 
ment sessions and there is no known home care device for laser treatment of RAS. Patients with RAS have recurrent ulcers and in-office treatment for each recurrent lesion needs several visits to office and consequent economic problems. Therefore, to assist patients to use lasers at home, a low level laser is inserted in a pen-like device.

As corticosteroids have several side effects, laser treatment may have some advantages for the treatment of recurrent aphthous stomatitis. In this clinical pilot study the laser pen as a home care device seems to be useful for treatment of RAS.

\section{References}

[1] Davatchi, F., Tehrani-Banihashemi, A., Jamshidi, A.R., Chams-Davatchi, C., Gholami, J., Moradi, M., et al. (2008) The Prevalence of Oral Aphthosis in a Normal Population in Iran: A WHO-ILAR COPCORD Study. Archives of Iranian Medicine, 11, 207-209.

[2] Chattopadhyay, A. and Shetty, K.V. (2011) Recurrent Aphthous Stomatitis. Otolaryngologic Clinics of North America, 44, 79-88. http://dx.doi.org/10.1016/j.otc.2010.09.003

[3] Rogers, R.S. (1997) Recurrent Aphthous Stomatitis: Clinical Characteristics and Associated Systemic Disorders. Seminars in Cutaneous Medicine and Surgery, 16, 278-283. http://dx.doi.org/10.1016/S1085-5629(97)80017-X

[4] Scully, C. (2012) Aphthous Ulcer. http://emedicine.medscape.com/article/867080-overview

[5] Safavi, S.M., Kazemi, B., Esmaeili, M., Fallah, A., Modarresi, A. and Mir, M. (2008) Effects of Low-Level He-Ne Laser Irradiation on the Gene Expression of IL-1Beta, TNF-Alpha, IFN-Gamma, TGF-Beta, bFGF, and PDGF in Rat's Gingiva. Lasers in Medical Science, 23, 331-335. http://dx.doi.org/10.1007/s10103-007-0491-5

[6] Pourzarandian, A., Watanabe, H., Ruwanpura, S.M., Aoki, A. and Ishikawa, I. (2005) Effect of Low-Level Er:YAG Laser Irradiation on Cultured Human Gingival Fibroblasts. Journal of Periodontology, 76, 187-193. http://dx.doi.org/10.1902/jop.2005.76.2.187

[7] Shimizu, N., Yamaguchi, M., Goseki, T., Shibata, Y., Takiguchi, H., Iwasawa, T., et al. (1995) Inhibition of Prostaglandin $\mathrm{E}_{2}$ and Interleukin 1-Beta Production by Low-Power Laser Irradiation in Stretched Human Periodontal Ligament Cells. Journal of Dental Research, 74, 1382-1388. http://dx.doi.org/10.1177/00220345950740071001

[8] Mesquita-Ferrari, R.A., Martins, M.D., Silva Jr., J.A., Dias da Silva, T., Piovesan, R.F. and Santos Pavesi, V.C. (2011) Effects of Low-Level Laser Therapy on Expression of TNF- $\alpha$ and TGF- $\beta$ in Skeletal Muscle during the Repair Process. Lasers in Medical Science, 26, 335-340. http://dx.doi.org/10.1007/s10103-010-0850-5

[9] Niemz, M.H. (2007) Laser-Tissue Interactions. Springer-Verlag, Berlin Heidelberg, 45-149.

[10] Tunér, J. and Beck-Kristensen, P.H. (2011) Low-Level Laser in Dentistry. In: Convissar, R.A., Ed., Principle and Practice of Laser Dentistry, Mosby Elsevier, 263-281.

[11] Tunér, J. and Hode, L. (1998) It’s All in the Parameters: A Critical Analysis of Some Well-Known Negative Studies on Low-Level Laser Therapy. Journal of Clinical Laser Medicine and Surgery, 16, 245-248.

[12] Enwemeka, C.S. (2009) Intricacies of Dose in Laser Phototherapy for Tissue Repair and Pain Relief. Photomedicine and Laser Surgery, 27, 1-7. http://dx.doi.org/10.1089/pho.2009.2503

[13] Mumcu, G., Sur, H., Inanc, N., Karacayli, U., Cimilli, H., Sisman, N., et al. (2009) Composite Index for Determining the Impact of Oral Ulcer Activity in Behcet's Disease and Recurrent Aphthous Stomatitis. Journal of Oral Pathology \& Medicine, 38, 785-791. http://dx.doi.org/10.1111/j.1600-0714.2009.00803.x

[14] De Souza, T.O., Martins, M.A., Bussadori, S.K., Fernandes, K.P., Tanji, E.Y., Mesquita-Ferrari, R.A., et al. (2010) Clinical Evaluation of Low-Level Laser Treatment for Recurring Aphthous Stomatitis. Photomedicine and Laser Surgery, 28, S85-S88. http://dx.doi.org/10.1089/pho.2009.2661

[15] Takahashi, K., Onoda, C., Sugiyama, S., Noro, A., Makiishi, T. and Ishikawa, T. (1987) Clinical Evaluation of GaAl-As Semiconductor Laser Diode (UNI-LASER) İrradiation in Treatment of Solitary Aphtha, Erosion and Hypersensitive Dentin. Shikwa Gakuho, 87, 295-303.

[16] Quang-Hua, W. and Shi-Yun, P. (1986) Clinical Study of Treatment of Recurrent Aphthae with the (He-Ne) Laser. Actual Odontostomatol (Paris), 40, 327-333.

[17] Prikuls, V.F. (2000) Experience in Irradiating with Helium-Neon Lasers to Treat Patients with Relapsing Aphthous Stomatitis. Stomatologiia (Mosk), 79, 20-22.

[18] von Ahlften, U. (1987) Experiences in the Treatment of Aphthous and Herpetic Oral Mucosal Diseases Using a New Infrared Laser. Quintessenz, 38, 927-933.

[19] Mikhaŭlova, R.I., Terekhova, N.V., Zemskaia, E.A. and Melkadze, N. (1992) The Laser Therapy and Laser Acupunture of Patients with Chronic Recurrent Aphthous Stomatitis. Stomatologiia (Mosk), 3, 27-28. 
[20] Kruszczyński, T., Kruszczyńska, J., Dziubiński, Z. and Pankowska, B. (1980) Treatment of Recurrent Aphthae by Photocoagulation with an Argon Laser. Czasopismo Stomatologiczne, 33, 787-790.

[21] Khademi, H., Shirani, A.M. and Nikegbal, F. (2009) Evaluation of Low Level Laser Therapy in Recurrent Aphthous Stomatitis. Journal of Dentistry, Shiraz University of Medical Sciences, 10, 160-162.

[22] Tezel, A., Kara, C., Balkaya, V. and Orbak, R. (2009) An Evaluation of Different Treatments for Recurrent Aphthous Stomatitis and Patient Perceptions: Nd:YAG Laser versus Medication. Photomedicine and Laser Surgery, 27, 101-106. http://dx.doi.org/10.1089/pho.2008.2274

[23] Demetriades, N., Hanford, H. and Laskarides, C. (2009) General Manifestations of Behçet's Syndrome and the Success of $\mathrm{CO}_{2}$-Laser as Treatment for Oral Lesions: A Review of the Literature and Case Presentation. Journal of the Massachusetts Dental Society, 58, 24-27.

[24] Salman, H., Kashmoola, M.A., AL-Waez, M.M. and AL-Sandooq, T.A. (2008) Differences between Low Level Laser Therapy and Triamcinolone Acetonide Kenalog on Healing of Recurrent Aphthous Ulceration. Annals of the College of Medicine Mosul, 34, 35-41.

[25] Kashmoola, M.A., Salman, H. and AL-Waez, M.M. (2005) Clinical Effect of Low Level Laser Therapy on Healing of Recurrent Aphthous Ulcer and Oral Ulceration in Behcet’s Disease. Journal of Baghdad College of Dentistry, 172, 36-40.

[26] Colvard, M. and Kuo, P. (1991) Managing Aphthous Ulcers: Laser Treatment Applied. Journal of the American Dental Association, 122, 51-53.

[27] Caputo, B.V., Filho, G.A.N., dos Santos, C.C., Okida, Y. and Giovani, E.M. (2012) Laser Therapy of Recurrent Aphthous Ulcer in Patient with HIV Infection. Case Reports in Medicine, 1-3. http://dx.doi.org/10.1155/2012/695642

[28] Albrektson, M. and Marklund, B. (2012) Can Low Level Laser Therapy Relieve Acute Symptoms of Recurrent Aphthous Stomatitis-A Randomized Clinical Study. Medicina Oral Patología Oral y Cirugia Bucal, 17, S263. http://dx.doi.org/10.4317/medoral.17643763

[29] Bladowski, M., Konarska-Choroszucha, H. and Choroszucha, T. (2004) Comparison of Treatment Results of Recurrent Aphthous Stomatitis with Low and High Power Laser Irradiation vs. a Pharmaceutical Method (5-Year Study). The Journal of Oral Laser Applications, 4, 191-209.

[30] Zand, N., Fateh, M., Ataie-Fashtami, L., Djavid, G.E., Fatemi, S.M. and Shirkavand, A. (2012) Promoting Wound Healing in Minor Recurrent Aphthous Stomatitis by Non-Thermal, Non-Ablative $\mathrm{CO}_{2}$ Laser Therapy: A Pilot Study. Photomedicine and Laser Surgery, 30, 719-723. http://dx.doi.org/10.1089/pho.2012.3301

[31] Zand, N., Ataie-Fashtami, L., Djavid, G.E., Fateh, M., Alinaghizadeh, M.R., Fatemi, S.M., et al. (2009) Relieving Pain in Minor Aphthous Stomatitis by a Single Session of Non-Thermal Carbon Dioxide Laser Irradiation. Lasers in Medical Science, 24, 515-520. http://dx.doi.org/10.1007/s10103-008-0555-1

[32] Basirat, M. (2012) The Effects of the Low Power Lasers in the Healing of the Oral Ulcers. Journal of Lasers in Medical Sciences, 3, 79-83.

[33] Sanchez, P.J.M., Femenias, J.L.C. and Tunér, J. (2013) Treatment of Aphthous Stomatitis Using Low Level Laser Therapy. Laser, 3, 18-20.

[34] da Silva, J.P., da Silva, M.A., Almeida, A.P.F., Lomdardi, I. and Matos, A.P.M. (2010) Laser Therapy in the Tissue Repair Process: A Literature Review. Photomedicine and Laser Surgery, 28, 17-21. http://dx.doi.org/10.1089/pho.2008.2372

[35] Howell, R.M., Cohen, D.M., Lynn Powell, G. and Green, J.G. (1988) The Use of Low Energy Laser Therapy to Treat Aphthous Ulcers. Annals of Dentistry, 47, 16-18.

[36] Albrektson, M., Hedström, L. and Bergh, H. (2014) Recurrent Aphthous Stomatitis and Pain Management with LowLevel Laser Therapy: A Randomized Controlled Trial. Oral Surgery, Oral Medicine, Oral Pathology and Oral Radiology, 117, 590-594. http://dx.doi.org/10.1016/j.0000.2014.01.228

[37] Enwemeka, C.S., Parker, J.C., Dowdy, D., Harkness, E.E., Sanford, L. and Woodruff, L.D. (2004) The Efficacy of LowPower Lasers in Tissue Repair and Pain Control: A Meta-Analysis Study. Photomedicine and Laser Surgery, 22, 323329. http://dx.doi.org/10.1089/pho.2004.22.323

[38] Woodruff, L.D., Bounkeo, J.M., Brannon, W.M., Dawes, K.S., Barham, C.D., Waddell, D.L. and Enwemeka, C.S. (2004) The Efficacy of Laser Therapy in Wound Repair: A Meta-Analysis of the Literature. Photomedicine and Laser Surgery, 22, 241-247. http://dx.doi.org/10.1089/1549541041438623 
Scientific Research Publishing (SCIRP) is one of the largest Open Access journal publishers. It is currently publishing more than 200 open access, online, peer-reviewed journals covering a wide range of academic disciplines. SCIRP serves the worldwide academic communities and contributes to the progress and application of science with its publication.

Other selected journals from SCIRP are listed as below. Submit your manuscript to us via either submit@scirp.org or Online Submission Portal.
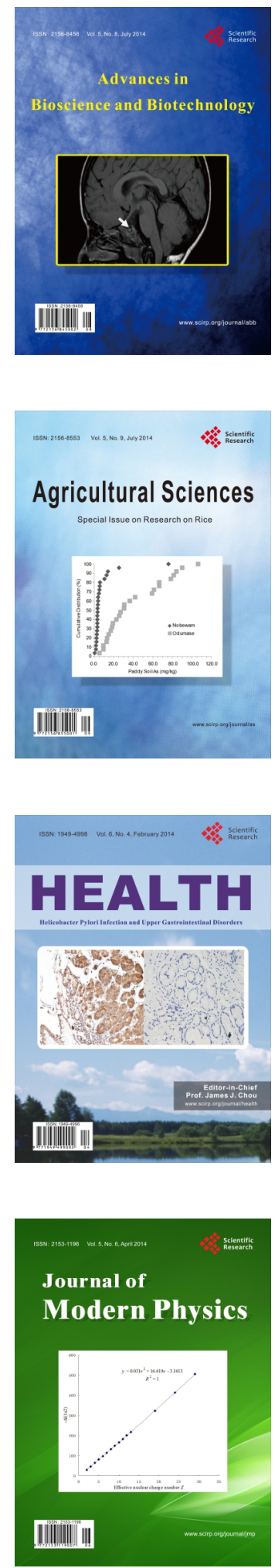
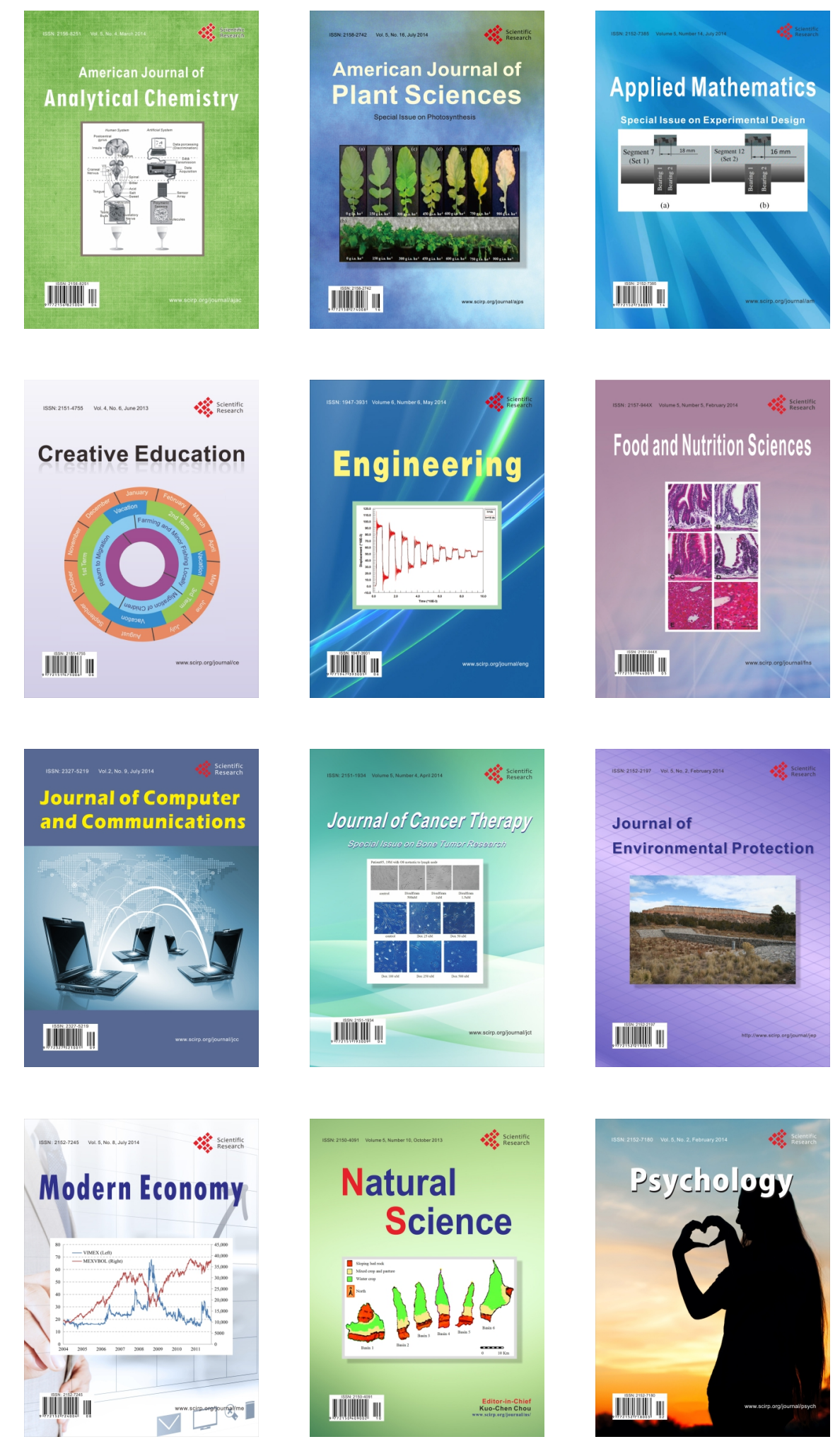